地すべり 第 29 巻 第 4 号

Journal of Japan Landslide Society 29-4(1993)

\title{
地すべり地における表面歪の分布と変化 \\ Distribution and Change of Surface Strain in a Landslide
}

\author{
川邊洋* 芝 野 博 文** \\ Hiroshi KAWABE Hirofumi SHIBANo
}

\begin{abstract}
The movements of many survey points that had been arranged about in a lattice at intervals of $2-4 \mathrm{~m}$ in a small-scale landslide were repeatedly surveyed by an electro-optical distance-meter. From the results of survey, the distribution and the changes of horizontal strain of the ground surface were obtained by the theory of two-dimensional finite homogeneous strain. Consequently, this method was proved very effective for the detection of local movements in a landslide and further for the acquirement of data on a forecast of a landslide and measures against it.
\end{abstract}

キーワード: 光波測量, 有限均一歪理崄, 表面歪, 地すべり地

\section{1.はじめに}

地すべり地の地表面の移動は，一般に伸縮計や移動杭 を用いて観測されてきたが，ここ十数年の間に光波測距 儀が急速に普及し, 地すべりの移動量の測定にも盛んに 利用されるようになってきた。一方, 移動量と並んで, 場合によってはそれ以上に重要な情報を含んているる歪に ついては, 移動量ほどには測定されていない。たとえば, 吉沢1) は光波測量結果を用いて測点の歪を考察し，また 金井2) は杭の移動量より表面歪を求め, 地すべりの変形 に検討を加えたが，いずれも測点数が少なく，地すべり 地全体にわたる歪の分布やその経時変化を求めるまでに は至っていない。

著者らはかつて自然斜面に人為的に地すべりを発生さ せ, 2〜 $4 \mathrm{~m}$ 間隔でほほ格子状に配置した杭の移動を光波 セオドライトで測量しだ3)。今回，その測量結果を用いて 地表面の歪を求め, その変形に考察を加えると同時に, そのような測量方法から表面歪を求めることによって, 地すべりの変動過程をどの程度明らかにすることができ るのかを確認することにした。

\section{2. 観測値の精度}

移動杭の配置は図-1 の通りである。光波測量用の測 点は 48 点あり, 試験地の西方 $150 \mathrm{~m}$ ほどの小尾根に光 波セオドライトが設置されている。実験の詳細は文献 3) を参照されたい。

今回の計算には，変形土体の影響を受けているE〜J

* 三重大学生物資源学部

*** 東京大学農学部
列を取り上げた。また実験期間を, 昭和 63 年 2 月 2 日午 後（実験開始） 6 日午後， 6 日午後 10 日午後， 10 日 午後 13 日午前, の 3 期間に分けて, 各期間毎の歪を求 めた。それぞれ，微小な変形の期間，変形が加速された 期間，変形速度が定常状態から若干鈍り始めた期間，に 相当する。なお, 実験中に試験地下端に近い J 列の測点 と丁度滑落崖にかかっていた $\mathrm{E}$ 列 3 番目の測点が不安 定となり，時間の経過とともに計算に使用できる測点は 減っていった。

ここで，計算に進む前に，観測值の精度について検討 する4)。

使用測器の測距範囲は約 $500 \mathrm{~m}$, 公称精度は $\pm 5 \mathrm{~mm}$, また測角の最小読み取りは $20^{\prime \prime} て ゙$ 目測で 1 "まで読むこと ができる。毎回距離測定は 5 回の読みの平均を取り, 測 角は 1 回のみである。測点と光波セオドライトとの斜距 離は約 $150 \mathrm{~m}$, 高低差は僅かである。また, セオドライト

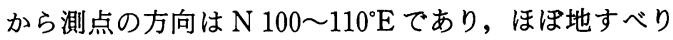
の移動方向にセオドライトが設置されている。

不動点との間の 22 回の測定より,データのばらつきは 次のようになった。なお, 斜距離には気象補正を施して あり，また水平角は基準点からの方位角である。

斜距離: 平均 $157.3042 \mathrm{~m}$, 標準偏差 $1.0 \mathrm{~mm}$ 水平角: 平均 $326^{\circ} 12^{\prime} 5.9^{\prime \prime}$ ，標準偏差 $13.2^{\prime \prime}$

高低角: 平均 $90^{\circ} 31^{\prime} 44.5^{\prime \prime}$ ，標準偏差 $7.7^{\prime \prime}$ ばらつきの度合を図 -2 に示す。斜距離のばらつきは 2 $\mathrm{mm}$ 程度に収まっており，公称誤差以内に入っている が, 測角誤差は \pm 20 秒の範囲にばらついている。上記の 標準偏差より誤差伝播の法則を用いて各座標の標準偏差 を求めてみると次のようになる。 


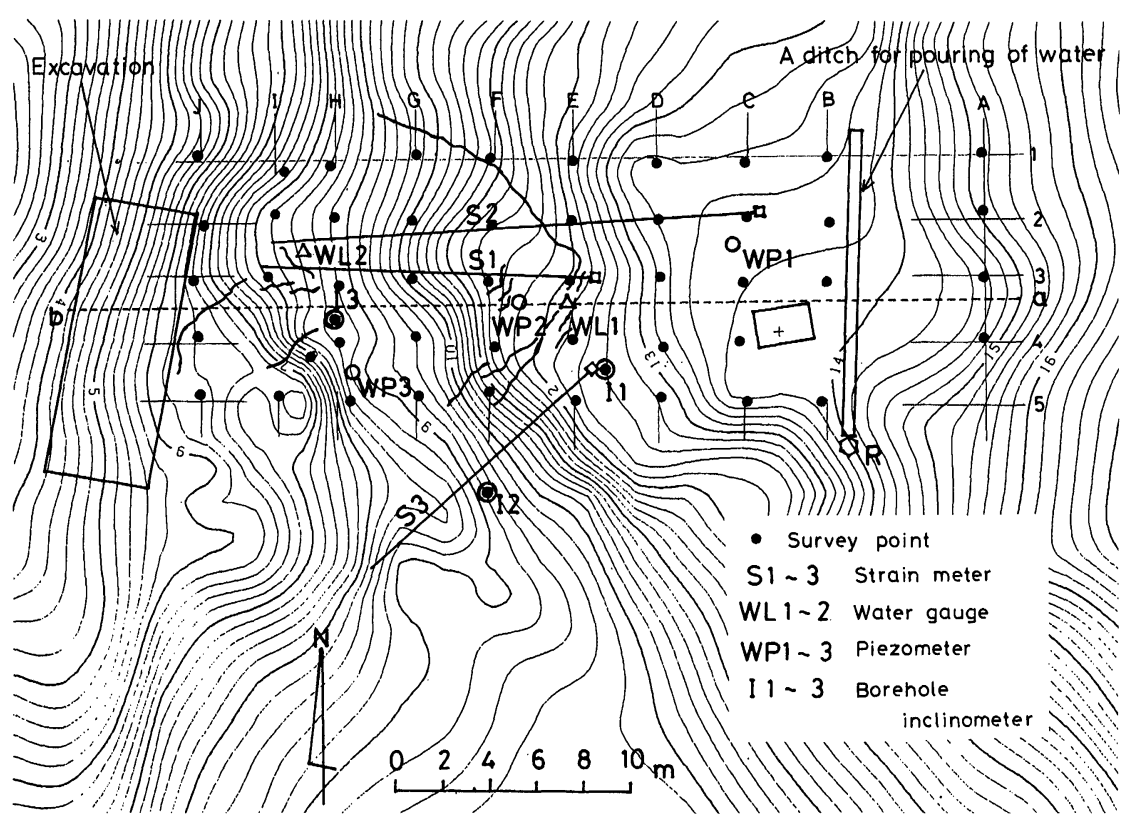

\section{図-1 試験地平面図}

The ground plan of the testing field

$\mathrm{X}: 9.7 \mathrm{~mm}, \quad \mathrm{Y}: 3.0 \mathrm{~mm}, \quad Z: 5.8 \mathrm{~mm}$ $\mathrm{Y}$ 軸方向で精度が比較的良いのは，この方向がセオドラ イトと測点を結ぶ方向とほほ一致しているからである。 これらの值から, 水平面内では $2 \mathrm{~cm}$ 以下の移動には信 頼性がないことになる。

したがって, 本論文では地表面の移動の状況を逐次追 跡していくことは断念し, 前述の三つの期間内での累積 の動きを抽出することにした。そのため, 各測点の履歷 を滑らかに近似できればよい。そこで，斜距離は比較的 誤差が少なく, 誤差関数で近似できるということと, 変 位ベクトルの方向に時間的にそれほどの振れはないとの 仮定のもとで，水平角と高低角について誤差関数をあて はめスムージングを行なった。すなわち, 斜距離には実 測值, 水平角と高低角にはスムージング後の值を用いて 各測点の座標を計算した。

\section{3 . 水平歪の計算方法と分布}

水平歪の求め方には, 測点間の距離の変化から計算す る方法 ${ }^{5,6)}$, 測点の座標の変化から計算する方法 ${ }^{7), 8)}$, など 種々の方法がある。ここでは原田7に倣って, 測点の座標 の変化量から二次元有限均一歪理論を用いて地表面の水 平歪を求める。すなわち, 新旧両座標の間に一次変換が 成り立つと仮定して, 三角形毎に歪を計算した。その結 果を, 図-3 (主軸とその伸縮率), 図一4 (面積歪) およ び図一5（最大剪断歪）に示す。

地すべり地に平面応力が働いた結果, 応力と同じ主方
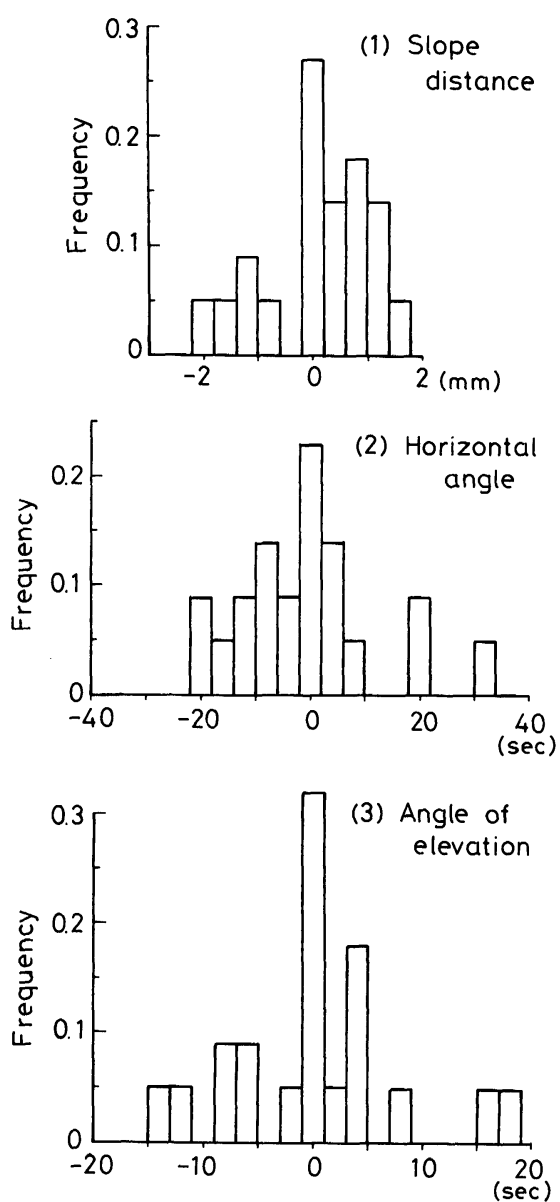

図ー2 観測值のばらつきの度合

The amount of scatter in measured values 


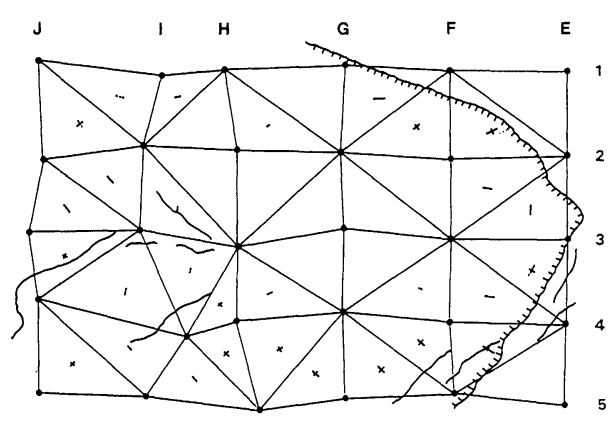

(1) Feb. $2 \sim 6$

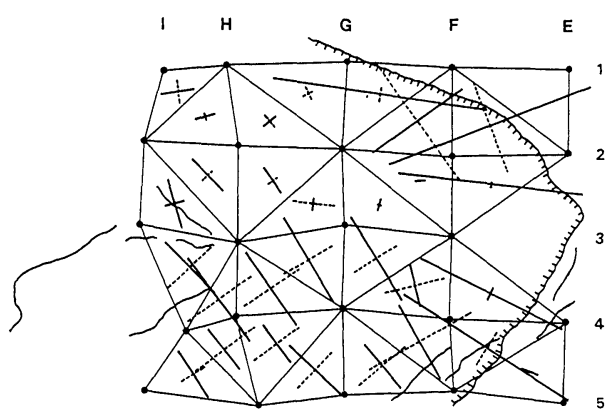

(3) Feb. $10 \sim 13$

図一3 各分割三角形における主歪の期別分布

Distribution of principal axes of strain in each triangular region

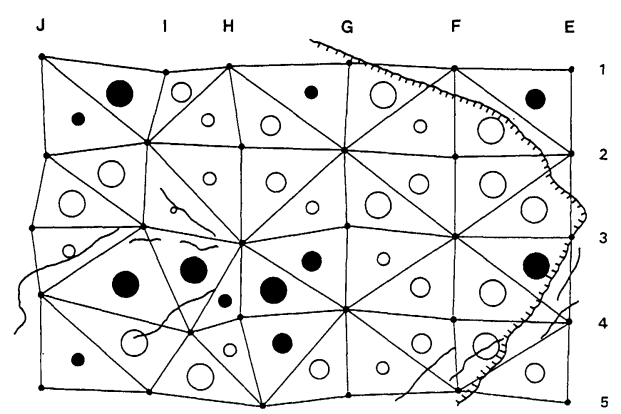

(1) Feb. $2 \sim 6$
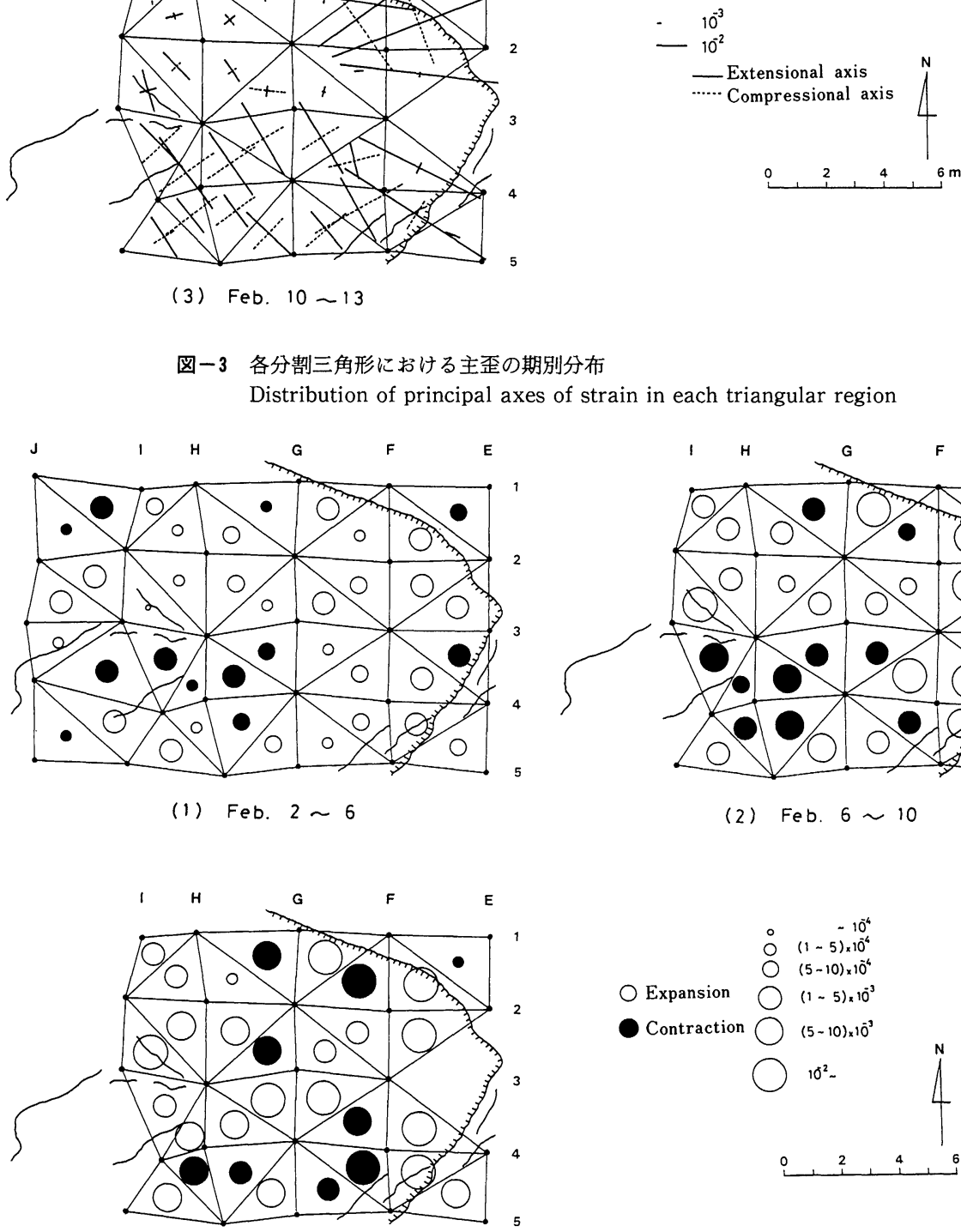

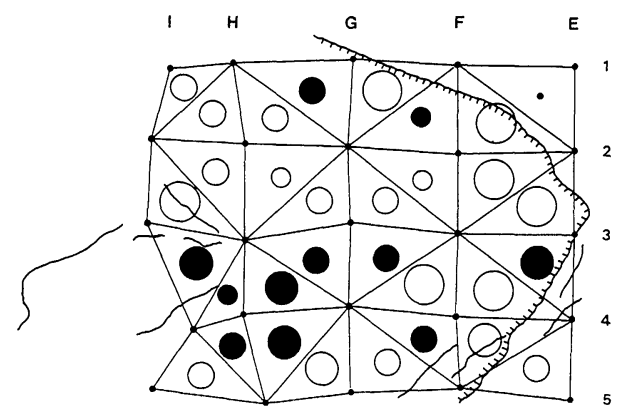

(2) Feb. $6 \sim 10$

(3) Feb. $10 \sim 13$

园-4 各分割三角形における面積歪の期別分布

Distribution of dilatation in each triangular region 


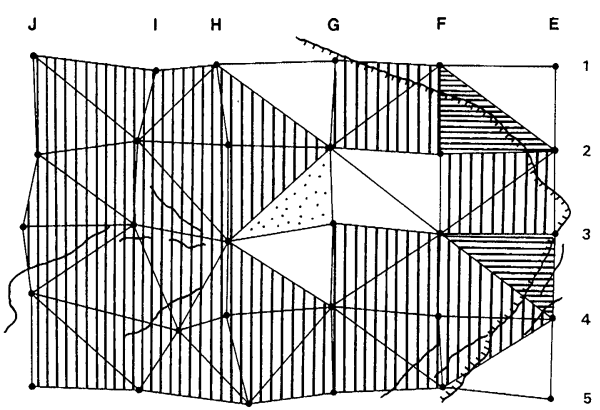

(1) Feb. $2 \sim 6$

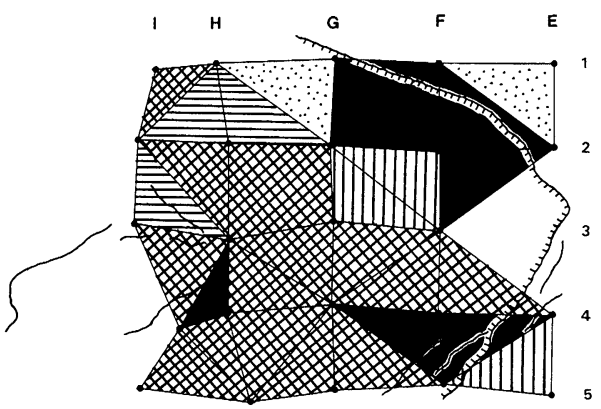

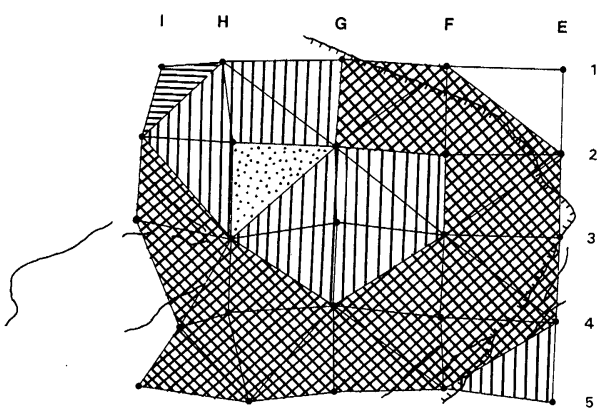

(2) Feb. $6 \sim 10$

\section{図-5 各分割三角形における最大剪断歪の期別分布}

Distribution of the maximum shear strain in each triangular region

向をもつ伸張あるいは圧縮歪が発生し，この歪により各 三角形に生じた面積変化を歪として表わしたものが面積 歪である。また, 平面応力あるいは歪の主方向と $45^{\circ}$ をな す方向に最大剪断歪が現われ，この方向に剪断クラック が形成される場合がある。クラックにはその他, 引張や 圧縮によって生じるものもある。図中には滑落崖とク ラックの位置も記入されている。なお, 移動杭の不安定 化のため, 各図の(2)では J 列の測点が欠け，(3)ではさら にE列 3 番目の測点が欠けている。

ところで, 地表には滑落崖やクラックが生じて, もは や連続体ではなくなっている。したがって, 各三角形毎 に均一歪を仮定するのは不合理であるが, クラックを生 じた三角形では, 計算された歪とクラックの存在の間に 定性的な関係, たとえば地表にクラックが発生するまで にどの程度の歪が生じていたかなどの関係を見い出すこ とはできるであろう。

\section{4 . 地すべり地表面の変形}

図-3〜 5 の(1)によると, 最初の期間（微変形期）に, 後に滑落崖が形成される一帯と試験地下部および試験地 南寄りの斜面に, 小さな歪が発生している。歪の大きさ は $10^{-3}$ のオーダーである。面積歪は全体的には膨張を示 しているが, $\mathrm{G} \sim \mathrm{J}$ 列かつ 3〜4 列に挟まれた区域（以後,
(G〜J，3〜4) のように表示) に収縮が見られるのが特徴 的である。

2 番目の期間 (加速期) になると滑落崖が形成され, そ こでは斜面中央に向かう大きな伸びと滑落崖にほほ平行 な収縮が観察される(図ー3(2))。主軸の方向にはほとん ど変化は見られない。滑落崖が形成されているところで は, 歪は $10^{-2}$ を超えている。滑落崖の走向と主軸の方向 から判断して, 滑落崖南半部は引張応力, 北半部は剪断 応力によりできたものと思われる。

（G～I，3〜4）の区域では，全体的な地すべりの移動 方向である東西方向ではなく, 北西一南東方向の伸張と それに直交する収縮が目に付く。この状況は，前述のよ うに，微変形期より面積歪に収縮となって現われており， 加速期ではさらにその収縮が強調されている（図一 4 (2))。恰も試験地の南西端付近に移動を妨げるようなブ ロックが存在し, 北東方向に圧縮力を及涩しているよう に見える。

斜面の中央から北西にかけての歪は小さい。これを反 映して, 大きい剪断稂は試験地を東〜南〜西と取り巻く ように分布している（図一5(2))。

3 番目の期間 (定常期) になると, 図一3(3)のように全 体的にさらに大きな伸張を示すようになり（場所によっ ては $10^{-1}$ に迫るほどの)，とくに(G〜I，3～5）の区域の 
北西一南東方向の伸びが著しい。これは, 試験地南西端 付近の障害物からの逃げ道が，その方向に見つかったか のような動きであり, 図ー4(3)に示すように,この区域の 面䖽歪が一転膨張に転じたことにもその変化がうかがわ れる。

また，上記のような主軸の方向を持つ（G～I，2～5） の区域と, 西南西一東北東方向に伸びの主軸を持つ（G 〜 I, 1〜2) の区域とは主軸の方向に大きな差があり, 異 なるブロックを形成していると推測される。

なお，試験地内には数本のクラックができているが, いずれも連続性が悪く, どのような応力状態で発生した のかを判断することはできなかった。

\section{5. 結 び}

小規模な地すべり地に多数配置した測点の移動を光波 セオドライトで測量し, 地表面の歪の分布およびその変 化を求めて検討を加えてきた。しかし, 歪計算の時間間 隔を短く取ると, その間の移動量が微小になり, 測量詔 差の影響を受けてしまうため, 斜面上での歪の伝播の様 子を追跡することはできなかった。

光波測量の精度を高めない限り, 歪の伝播を逐一追っ ていくことは難しいが，本文の方法をより広い面積の活 動的な地すべり地に適用することによって, 歪や歪速度 の分布, その時間的な変化, さらにはブロックの分割や より活動的なブロックの抽出, その経時的な動きなど,
地すべりの予測あるいは対策のための有力な資料を得る ことができるであろう。

本研究を進めるにあたり, 東京大学農学部砂防工学教 室の執印康裕助手と三重大学生物資源学部山地保全学研 究室学生の江上 泰君には, 文献収集や計算に際して御 助力いただいた。ここに記して感謝の意を表する。

\section{参考文献}

1) 吉沢孝和: 奈良尾地すべり地における地すべり挙動の精 密測量とその解析, 地すべり, Vol. 15, No. 3, pp. $11-16,1978$

2 ）釜井俊孝: 小川村袖地地すべりの変形像一表面ひずみ速 度テンソルの測定とその応用一, 地すべり, Vol. 26, No. 2, pp. $1-8,1989$

3 ）川這洋・芝野博文・西尾邦彦・山口伊佐夫: 野外実験に よる地すべり発展過程における地盤の変形特性, 地すべ り, Vol. 27, No. 1, pp. 1-10, 1990

4) 川上 浩: 地すべり調査に関連する 2,3 の問題, 地質学 論集, No. 28, pp. 87-95, 日本地質学会, 1986

5 ) 橋本 学: 測地測量により求めた日本列島の地震間の平 均的な地殼水平歪速度（I）本州・四国・九州, 地震（第 2 輯), Vol. 43, No. 1, pp. 13-26, 1990

6 ）佐藤 裕: 測地学の基礎, pp. 112-117, 山海堂, 東京, 1984

7 ) 原田健久: 測地観測量網平均汎用プログラムの改良（歪 の計算を追加), 測地学会誌, Vol. 17, No. 1・2, pp. $1-3,1971$

8 ）檀原 毅・友田好文: 測地 - 地球物理, pp. 78-80, 共立 出版, 東京, 1969

（原稿受理日 平成 4 年 6 月 30 日）

\section{日本学術会議だよりN 0.27}

日本学術会議広報委員会より「秋の総会開催される」と標題した平成 4 年 11 月発行の日本学術会議だより №.27 が送付 されています。主な内容は下記の通りですが，コピーを御入用の方は地すべり学会事務局にお申し越し下さい。

\section{1.日本学術会䣧第 115 回総会}

(第 15 期・第 4 回，平成 4 年 10 月 21 日 23 日開催） 報告について

\section{2. 平成 4 年度日米学術交流について}

（会長談話）

\section{3. 学術分野における国際貢献について}

(会長談話)

\section{4. 日本学術会議主催公開雃演会}

「科学技術を通じての国際貢献」 平成 5 年 2 月 22 日 
高速リングせん断試験機による土砂の運動時の内部摩擦角の測定

「地すべり」Vol. 29, No. 4 (通巻第 112 号) pp. 1 8, 1993 年（平成 5 年） 3 月

佐々 恭二, 福岡 浩

地すべり運動時に発揮される内部摩擦角は，通常のせん断試験で得られる内部摩擦角とは必ずしも同じではな いと思われる。そこで実際の地すべりの運動に刘応する速度でせん断抵抗を計測することを目的として, 表層崩 壊などを研究対象とした低圧用 $(39 \mathrm{kpa})$ の高速リングせん断試験機と地すべりを研究対象とした高圧用 $(390$

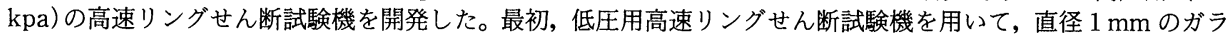
スビーズについて予備試験を行い，間隙流体の粘性抵抗は，表層崩壊に対応する $(10-40 \mathrm{kpa}$ 程度）低い垂直応 力のもとでも摩擦抵抗に比べて無視し得ることを確認したっついで, 高速高圧リングせん断試験機を用いて御岳 大崩壊や地附山地すべりの土など種々の土について $0.01 \mathrm{~cm} / \mathrm{sec}-100 \mathrm{~cm} / \mathrm{sec}$ のせん断速度で試験を行った。そ の結果, 得られた内部摩擦角は土によって挙動が異なり, せん断速度の增大により内部摩擦角が增大するもの, 逆に減少するもの, ほとんど変化しないものがあった。しかしその変化は一 -3.2 度から +3.7 度までの範囲にあ り，それほど大きなものではなかった。これらの内部摩擦角の变化の原因としては，せん断中の粒子の破砝によ る粒度分布と粒子形状の変化が考えられ，また，比較的粒径がそろっている材料では，粒子がせん断方向に配列 する影響があると思われた。

地すべり粘性土の一面せん断試験における破壊の伝播過程

「地すべり」Vol. 29, No. 4 (通巻第 112 号) pp. 9 17, 1993 年（平成 5 年） 3 月

金井 俊孝, 宮田雄一郎

地すべり粘土の定体積一面せん断試験を行い，供試体内部における破壊面の発達過程について，特に破壊の伝 播速度の観点から検討を加えた。試料には福島県与内烟地すべりから採取された粘土,カリオン HA, ベントナイ 卜を用意し, 直径 $6 \mathrm{~cm}$, 高さ $2 \mathrm{~cm}$ の円盤状共試体沉導電性塗料を塗布した 6 本の素麵マーカ一をせん断方向に 対して縦列に配置し, せん断した。せん断に先だってこれらの電極に $5 \mathrm{~V}$ の電圧を加え, 供試体の変形とせん断 によって電圧が逐次的に低下する状況を記録した。軟 X 線写真による観察から, これらの電極の切断プロセス は，供試体内部における破壊面の発達過程を的確に表現していることが明らかにされ，この電極の開発によって 破壊の伝播速度を議論することが可能になった。

モデル化された切土斜面の 3 次元安定解析と留意点

「地すべり」Vol. 29, No. 4 (通巻第 112 号) pp. 18〜24, 1993 年（平成 5 年） 3 月

鵜飼 恵三, 萩原 敏行, 井田 寿朗

モデル化された切土斜面に対して簡便分割法と弾塑性 FEM を用いた 3 次元安定解析を行い分割法を適用する

際の留意点を示し，現実に近いすべり面形状の予測には弾塑性 FEM を用いることが有効であることを指摘した。

\section{試料の準備方法の違いが粘性土のせん断特性に及ぼす影響}

「地すべり」Vol. 29, No. 4 (通巻第 112 号) pp. 25〜31，1993 年（平成 5 年）3月

重井 健史, 佐野 博昭

本研究では, 試料の準備方法の違いが粘性土のせん断特性に及ぽす影響を解明するために, 乱さない試料と練 返し再圧密試料に対して圧密定体積一面せん断試験を行った。

その結果, 乱さない試料と練返し再圧密試料の強度・変形特性は, 大きく異なることが定量的に示された。こ のことより, 練返し再圧密試料より得られたせん断強さを実地盤に適用した場合, 得られた解析結果は, 実地盤 の安定性を過小評価している可能性があることを示唆した。

地すべり地における表面歪の分布と変化

「地すべり」Vol. 29, No. 4 (通巻第 112 号) pp. 32〜36, 1993 年（平成 5 年） 3 月 川逶洋, 芝野 博文

小規模な地すべり地に, $2 \sim 4 \mathrm{~m}$ 間隔でほほ恪子状に配置した多数の測点の移動を, 光波セオドライトを用いて 繰り返し測量した。そのデー夕に二次元有限均一歪理論を適用して, 地表面の水平歪の分布と経時変化を求めた。 その結果, この方法は地すべりの局所的な変動の検出や予測のためのデー夕の取得に非常に有効であることが明 らかになった。

\section{地震とマスムーブメント}

「地すべり」Vol. 29, No. 4 (通巻第 112 号) pp. 37〜44, 1993 年（平成 5 年）3 月

中山 康

斜面の地震災害には, 岩石斜面の崩落と土砂斜面の滑動がある。前者は大きな加速度（すなわち力）で, 後者 は大きな仕事 work で発生する。斜面における加速度は震度 (最大加速度)で表現される。斜面滑動に関与する仕 事は, 震源のマグニチュード・震央距離で定まる到達エネルギーのうち波形に基づく何割かが転化したものであ る(波形が人工的な正弦曲線の場合, この割合は 0 となる)。

このため, 地震災害のハザードマップは 2 種類必要となり,「最大加速度」ならびに「マグニチュードと震央距 離」についての確率を知ることになる。 